\title{
Tourism Industry Partnerships: Partnership Opportunities for MSMEs and Large Business in Palembang City
}

\author{
Meitolo Hulu ${ }^{1, *}$ Reagan Brian ${ }^{2}$ Dilla Pratiyudha ${ }^{3}$ DanielSihombing ${ }^{4}$ Elang Kusumo ${ }^{5}$ \\ ${ }^{1}$ Universitas Pelita Harapan, Tangerang \\ ${ }^{2}$ Universitas Pelita Harapan, Tangerang \\ ${ }^{3}$ Politeknik Pariwisata, Palembang \\ ${ }^{4}$ Politeknik Pariwisata, Palembang \\ ${ }^{5}$ Universitas Pelita Harapan, Tangerang \\ *Corresponding author.Email: meitolo.hulu@uph.edu
}

\begin{abstract}
The era of globalization demands product innovation and competitiveness, followed by HR capabilities and digital marketing. This is an obstacle to the development of MSMEs that are competitive and support the community's economy. Micro, Small and Medium enterprises and large businesses in the tourism sector are not only supporting the community's economy but also as an effort to meet the needs of tourists while visiting destinations, and one of them is Palembang City. For this reason, MSME products such as crafts and culinary in Palembang city need to be strengthened through partnerships with large businesses. This study aims to examine the partnership opportunities of MSMEs and large businesses in the tourism sector that focus on the quality of human resources, regulations, funding and market in Palembang City. This paper aims to examine that behind the strengthening programs carried out by the government, there are many difficulties that are being faced by MSME actors in partnering. Data were analyzed using NVIVO12 software for coding, categorize and merging themes and then interpreting the data. The results of the study indicate that the quality of MSME human resources in Palembang City still requires various training and knowledge regarding business management and product innovation.
\end{abstract}

Keywords: Tourism MSMEs, Large business, Local Government, Partnership Opportunity.

\section{BACKGROUND}

The pandemic covid-19 that has hit the world today has had a negative impact on several sectors, and particularly in the tourism sector. Restrictions on community mobility hinder the movement of the economy which ends in the cessation of tourism activities. The Indonesian government through related institutions has formulated several policy schemes to adapt during the Covid-19 pandemic, one of which is the Ministry of Tourism through the CHSE (Clean, Hygiene, Safety, Environment) program for all tourism businesses. One of the national economic recovery programs is the priority of support for MSMEs (Micro, Small and Medium Enterprises) through cash and non-cash assistance schemes.
Based on data from the Ministry of Cooperatives and MSMEs, there are 1,554.65 MSMEs in Palembang City with various types of businesses, both individually and in groups. The number of accommodation businesses in 2020 is 53, restaurant businesses in 2020 are 864, and the number of foreign tourist visits through Sultan Mahmud Baddarudin Airport in 2019 is 15,846. During the Covid-19 pandemic, the level of tourist visits in all regions in Indonesia decreased, including the city of Palembang due to the implementation of health policies and protocols.

The tourism industry and the creative economy on the scale of MSMEs in Palembang City are experiencing problems related to human resources, access to capital, licensing information, and market access. 
MSME products that have distinctive characteristics and at the same time have superior value cannot be distributed and accepted by the market due to unattractive packaging. In addition, production capacity is also constrained by limited human resources, access to permits, access to financing, market access and at the same time the equipment used is still on a conventional basis. So that access to capital from financial institutions is not only constrained by a number of required conditions but also due to limited information to MSME actors. The era of globalization demands innovation in products and has competitiveness, but must be followed by human resource capabilities and digital marketing patterns. This is an obstacle to the development of MSMEs that are competitive and support the community's economy.

MSMEs and large businesses in the tourism sector are not only a supporter of the community's economy but can meet the needs of tourists while in the city of Palembang. MSME products such as handicrafts and culinary have become a benchmark for the development of tourist destinations in several cities in Indonesia; including Yogyakarta and Bali. Hotel tourism businesses, restaurants and tourist areas set standards that must be met in accommodating a product, namely quality. SMEs based on local wisdom products must innovate in order to create attractiveness and an authentic image for tourists. Thus, MSME product innovation demands quality human resources. In addition to the quality of human resources, the development of MSMEs also requires support for licensing, financing, and product marketing so that they can be distributed sustainably.

This paper aims to specifically show the condition of the quality of human resources, access to licensing, access to financing, and access to marketing for SMEs in Palembang City. In addition to identifying the types of difficulties faced, this paper also shows the criteria that must be met by MSMEs in order to have the opportunity to partner with large businesses. MSME partnerships with big businesses are a burden for MSME actors and also the government. Distribution of MSME products through partnership programs with large businesses as an effort to increase MSME product production which requires a number of criteria that must be agreed upon. In other words, this paper aims to examine that behind the strengthening program carried out by the government, there are many difficulties that are being faced by MSME actors in partnering.

\section{LITERATURE REVIEW}

\subsection{Quality of Human Resources}

A pervasive challenge in the tourism sector at large is persistent skill and labor shortages, limiting the ability of economies to achieve development benefits from the growth in tourism spending worldwide. The lack of skills applies to both 'hard, technical or jobspecific skills as well as 'soft' skills related to customer service and personal interactions. A common challenge faced by MSMEs in the tourism sector is a lack of supply of sufficiently skilled workers, which are required to move to higher-value added activities. If growth in tourist arrivals exceeds growth in a sufficiently skilled tourism workforce, benefits from growth cannot be maximized for the domestic economy [7]

MSMEs, in the tourism sector in particular, lack human resource development capacity as a consequence of their size, while management skills and adequate policies for career development are also lacking, which creates recurrent hiring and training costs which hinder productivity and profitability in the industry [18]. Thus, career structures tend to be flat, with limited opportunities to develop skills that are valued higher by the tourism market, such as management skills; this is a consequence of the larger number of firms in the sector and small-scale of businesses, which limits the ability to progress within a single firm [2]. The crowded nature of the sector combined with seasonal revenue flows makes financing formal training and recruitment difficult, thus MSMEs rely on ad-hoc and informal training which is entirely dependent on the skills of existing employees [7]. These circumstances create recurrent hiring and training costs and lead to a loss of expertise and institutional knowledge within firms due to turnover, which hinders productivity and profitability in the industry [18].

A compounding issue for these challenges is limited uptake of government training programs observed in the APEC Tourism Workforce Survey, with responses indicating a lack of awareness and potentially limited resources to take advantage of the programs as specific challenges. General challenges with government support that were observed include a general lack of funds by agencies, as well as a lack of awareness among MSMEs of the programs existence or how to access them [7]. Other identified challenges from this survey included regulatory burdens associated with hiring and employment; this was noted as the most critical challenges in a report 
regarding the tourism workforce in Australia [20]. The OECD identified difficulties attracting youth to these programs as a challenge.

There are also numerous challenges associated with formal education and training programs for tourismrelated occupations, which can include outdated course content and modes of teaching, as well as a lack of balance between theory and practice [18]. The European Commission found that there was a limited availability and provision of formal training, difficulties in making the business case for training and a lack of evaluation of the impact on staff, customers and businesses [12]. A critical deficiency among formal education and training programs provided through academic institutions can be a lack of reflection of industry needs in curricula. This can be attributed to a lack of engagement between industry and providers of training. As a consequence graduates of programs lack the skills necessary to attain employment in the sector, which can potentially contribute to the common perception that there are a lack of good careers in tourism businesses are unable to find quality workers, leading to difficulty in hiring and retaining employees, increasing value-added and creating a pipeline of skilled managers and other professionals [7].

\subsection{Funding}

Invest in expansion, capability development and other activities. Barriers are faced in securing funding from private actors and government agencies that include: lending arrangements that are not conducive to MSMEs; risk aversion by institutions that lend to MSMEs; poor financial literacy of MSMEs; informality and; bureaucratic delays in accessing government sources of capital, among others. The International Finance Corporation (IFC) found a financing shortfall for MSMEs exceeding \$2 trillion, or an estimated one-half to two-thirds of all formal MSMEs [19]

The main challenge for MSME finance is informational asymmetries between the bank and enterprise; the MSMEs are unable to produce the necessary information to demonstrate creditworthiness. The legal foundation and institutional structure for lending generally does not support the use broad range of collateral and nontraditional data for risk-based lending, which are critical for MSME access to finance [6]. Tourism MSMEs in particular face additional challenges since banks perceive additional risk associated the sector, due to factors such as "the production of servicebased intangibles, participation in global markets, high number of lifestyle entrepreneurs and family-run businesses, seasonal business cycle []15" The Council of Tourism Associations of British Columbia noted this challenge in a 2006 report on financing tourism enterprises [16], while Innovation, Science and Economic Development Canada regularly publishes analysis of tourism SME challenges in accessing capital, including higher perceptions of risk by financial institutions leading to requirements for collateral or detailed earnings data, seasonality and high cost of debt Trends in the "evolution of capital, liquidity, customer due diligence" requirements also pose disadvantages to MSMEs [6]. MSMEs rely primarily on debt financing, and these factors make it difficult to demonstrate the level of risk accurately to banks. This challenge is exacerbated by the simple fact that the MSME market is characterized by low revenue per client for banks [19].

MSMEs can face difficulty in attaining long-term loans for business expansion from banks due to failures in financial markets, meaning that banks do not offer an adequate supply despite the existence of demand. APEC has noted access to finance as a development deficiency for MSMEs in the tourism sector since 2004, with specific challenges including "collateral, cash flow, costs of training and technology and ability to ride out crises" and other access issues in accessing capital posed by "recent unemployment or redundancy and a lack of credit history," [2].

A challenge faced to access public sources of capital for MSMEs may be simple lack of awareness of such programs, in addition to limited resources. Furthermore, there may be significant amounts of paperwork or other bureaucratic delays that either discourage or preclude greater participation by MSMEs.

\subsection{Regulations}

From economy to increasingly local levels of government, bureaucratic processes and regulations related to trade and business can harm MSMEs in integrating into GVCs. Challenges may include high complexity, inconsistency and a lack of timeliness, which can increase the time necessary for MSMEs to start and grow their businesses, as well as receive various certifications and permissions [5]. Redundant domestic regulations and trade-related bureaucratic disruptions can create challenges for MNC expansion and thus limit MSME opportunities.

Certifications and permissions for activities such as tours and wellness services can create challenges for 
numerous reasons. Given that adventure activities involve risk to clients, acquiring permits in some cases requires long running engagement with multiple bureaucratic authorities, as observed in an APEC study in 2004 in the adventure tours segment in Mexico. The same study also suggested that certifications were potentially utilized by some administrative authorities in China to increase barriers to enter certain segments such as massage and property management, rather than primarily to ensure quality and legitimacy of the products and services [7].

Additionally, an APEC workshop identified challenges associated with government efforts to increase training amount the tourism workforce, which included regulatory burdens associated with government training programs and poor uptake of government training programs [7]. On the other hand, there can also be challenges associated with a lack of government oversight of labor in tourism MSMEs, including unsafe working conditions and a lack of labor protections, in which disadvantage workers can be exploited due to shirking of regulations [7].

Another challenge related to informality is that since bureaucratic authorities lack the capacity to fully enforce business registration requirements and regulations, many MSMEs in the informal sector can bypass the investment of time and resources needed to be a formal enterprise. This limits the tax base for local governments while also creating unfair competition for formal MSMEs [4]. The lack of enforcement of regulations and low labor standards can also create a race to the bottom in terms of prices and other anti-competitive practices by larger firms, which can potentially crowd out MSMEs [7].

Government of Indonesia seriously support the development of MSMEs, marked by the stipulation of a number of regulations both related to licensing, taxes, financing and at the same time regulating partnerships between business actors. Through this policy, various facilities are provided to MSME actors with the aim of developing, creating new business actors and at the same time expecting quality MSME products. The following are the regulations that have been set for the framework of strengthening MSMEs:

- Government Regulation of the Republic of Indonesia Number 17 of 2013 concerning the Implementation of Law Number 20 of 2008 concerning Micro, Small and Medium Enterprises.
- Presidential Regulation No. 98 of 2014 concerning Micro and Small Business Licensing.

- Regulation of the Minister of Home Affairs No. 83 of 2014 concerning Guidelines for Granting Micro and Small Business Permits.

- Regulation of the Coordinating Ministry for the Economy No.23 of 2017 concerning Guidelines for the Implementation of People's Business Credit.

- Government Regulation No. 23 of 2018 concerning Income Tax on Income from Businesses Received or Obtained by Taxpayers Who Have a Certain Gross Circulation.

- Government Regulation No. 7 of 2021 concerning Ease, Protection, and Empowerment of Cooperatives and Micro, Small, and Medium Enterprises.

\subsection{Market}

MSMEs face a number of challenges in integrating into tourism GVCs and accessing higher value-added opportunities due to the market structure of the tourism sector, related to both lead MNCs and larger enterprises, as well as competition from other MSMEs. The OECD and WTO found that MNCs' decision to engage with MSMEs is based on a number of factors, including: product specifications; production cost; production capacity; market size; financial soundness; flexibility; delivery; compliance ability (standards and certification); innovation capacity; transport capacity and; labor skills.

MSMECs and larger enterprises are very cautious about choosing MSME suppliers and assess their capabilities from multiple perspectives [3]. This can create barriers for MSMEs with limited resources to invest in capacity building, expansion, new technology, etc., given that the number one most valued factor by MNCs is product quality. This means that if an MSME's product or service isn't already at the standard demanded by MNCs, it will likely not even be considered in the supplier selection process [3].

\subsection{Partnership Opportunities}

Determination of regulations is the government's full support in developing MSMEs [17] [1]. The management of MSMEs, which are still individual in nature, encounters many obstacles both in material and non-material aspects in their development. The non-material aspects faced by MSMEs are the readiness of human resources, effective management [23], and marketing of their products [11]. So now, managerial aspects and the use of technology in developing MSME products are a must in 
competitive MSME operations. In terms of strengthening MSMEs, it is inseparable from the capital regulated in regulations [1] to support operational activities and increase production capacity.

tourist destinations require a range of amenities, as well as supporting facilities and services. This sector has unique characteristics because most of its ownership and operations are carried out by MSMEs. Accommodation, culinary and craft businesses are businesses managed by local communities based on MSMEs. The management of MSMEs, which are still individual in nature, encounters many obstacles, both in material and non-material aspects in their development.). The non-material aspects faced by MSMEs are the readiness of human resources and effective management [23]. In addition, the use of technology in developing MSME products is a must in competitive MSME operations. The condition of MSMEs that experience a number of limitations must have a variety of innovations to increase production results and the capacity of MSMEs themselves [22]. Because innovation is evidence of quality human resources [14] and the growth of SMEs itself.

The existence of MSMEs in the tourism sector is a supporting factor for a tourist destination. The growth of MSMEs has contributed positively to economic improvement [14], and at the same time opens up opportunities to absorb labor, even though they still have a small production capacity. However, MSMEs also have limitations in terms of investment and management expertise currently required by the tourism industry market [10]. The diverse nature of tourism products, intersect, and depend on each other makes companies have to create cooperative relationships with various stakeholders, namely suppliers, distributors, competitors, governments, and other companies that make up the tourism supply chain [21]. So that partnerships are important in order to keep product distribution smooth. However, in industries that have intensively coordinated, there are still risks due to the high dependence on the supply chain [21].

Based on the theory described above, strengthening MSME partnerships with large businesses through the supply chain requires a concrete form. In this study, the focus is on strengthening MSMEs in the tourism sector in order to improve the quality of human resources, access to permits, access to financing/capital and market access.

\section{METHODS}

This type of research is descriptive qualitative to obtain data that describes the topic being studied,

Table 1. Perspective of MSME

\begin{tabular}{|c|c|c|c|}
\hline No & Focus of Study & Indicators & Description \\
\hline \multirow[t]{5}{*}{1} & \multirow{5}{*}{$\begin{array}{l}\text { Human Resources } \\
\text { Quality and Production } \\
\text { Capacity }\end{array}$} & Employee Skills & Require Training \\
\hline & & Ability to manage business & Requires training \\
\hline & & MSME HR needs training & Requires training \\
\hline & & Products are able to compete & Requires product innovation training \\
\hline & & $\begin{array}{l}\text { MSME products through the Quality } \\
\text { Control process }\end{array}$ & Need product standardization \\
\hline \multirow[t]{4}{*}{2} & \multirow[t]{4}{*}{ Access to Permits } & Ease of taking care of permits & Facing problems \\
\hline & & MSMEs have a business license & Most do not have one \\
\hline & & Registered MSME brand & Still not registered \\
\hline & & Permit to sell abroad & Most do not have access and information \\
\hline \multirow[t]{3}{*}{3} & \multirow[t]{3}{*}{ Access to Finance } & $\begin{array}{l}\text { The government socializes financing } \\
\text { institutions }\end{array}$ & There are some MSMEs do not know \\
\hline & & $\begin{array}{l}\text { MSMEs are given the ease way of } \\
\text { getting capital }\end{array}$ & $\begin{array}{l}\text { There are MSMEs who have not felt the } \\
\text { ease of getting capital }\end{array}$ \\
\hline & & Assistance by financial institutions & $\begin{array}{l}\text { Some of MSME not yet receiving } \\
\text { assistance from financing institutions }\end{array}$ \\
\hline \multirow[t]{6}{*}{4} & \multirow[t]{6}{*}{ Access to Marketing } & $\begin{array}{lll}\begin{array}{l}\text { MSME development } \\
\text { exhibitions }\end{array} & \text { through } \\
\end{array}$ & Not all MSMEs can participate \\
\hline & & $\begin{array}{l}\text { The policy of using MSME products by } \\
\text { large businesses is }\end{array}$ & Still not implemented \\
\hline & & $\begin{array}{l}\text { The policy of using MSME products by } \\
\text { local government businesses }\end{array}$ & Still not implemented \\
\hline & & The government provides a show case & Not yet available \\
\hline & & $\begin{array}{l}\text { Large businesses open themselves to } \\
\text { using MSME products }\end{array}$ & With a number of requirements \\
\hline & & $\begin{array}{l}\text { The government provides a digital } \\
\text { platform for MSMEs }\end{array}$ & $\begin{array}{l}\text { Through the GIWANG application, but } \\
\text { not all have registered yet }\end{array}$ \\
\hline
\end{tabular}

Source: Processed data, 2021 
namely understanding the characteristics of the condition of the object and research subject, understanding ideas that arise in the field, and assisting in making decisions [8]. The qualitative approach used is a case study, namely strengthening MSME partnerships in the tourism sector in Palembang City. Primary data collection was done through focus group discussion, interviews and field observations. The focus group discussion was conducted to collect data collectively on the condition of the quality of human resources from MSME actors, to find out about programs related to human resource development from the regional government, and CSR programs carried out by large businesses related to human resource development.

The selection of informants was carried out by purposive sampling, namely deliberately choosing according to their capacity and involvement in the context of strengthening MSMEs in the city of Palembang. Each informant, namely; from the relevant local government consists of two people, five people from SMEs, and three people from big business actors. Field observations were carried out for two days to observe directly the condition of MSMEs, restaurants, hotels, and tourist areas in order to strengthen partnership opportunities. In addition to primary data, secondary data collection is also carried out through literature searches and regulations related to strengthening MSMEs in Palembang City. The collected data is then analyzed using the NVIVO12 software for coding, categorizing and combining themes and then interpreting it.

\section{RESULTS}

The tourism industry in Palembang City is mostly dominated by MSMEs which in their operations encounter a number of obstacles in developing their business caused by several factors. In this study, MSMEs in the tourism sector and large businesses, namely hotels, restaurants, and tourist areas are the objects in this study. This study focuses on aspects of the quality of human resources and MSME production, access to MSME licensing, access to MSME financing, and access to MSME marketing. The local government as a regulator is inseparable in this study related to programs in developing MSMEs and implementing regulations. Local government support in synergizing partnerships between big businesses (hotels, restaurants, tourist areas) and MSMEs is assessed through interviews, focused discussions, and observations. The following are the results of interviews, focused discussions, and

Table 2. Perspective of Local Government

\begin{tabular}{|c|c|c|c|}
\hline No & Focus of Study & Indicators & Description \\
\hline 1 & \multirow{3}{*}{$\begin{array}{lr}\text { Human } & \text { Resources } \\
\text { Quality } & \text { and } \\
\text { Production Capacity }\end{array}$} & Training & Training conducted by program \\
\hline & & Product Innovation & MSME products are still not diverse \\
\hline & & Product Quality & $\begin{array}{l}\text { Need to set product standards in order to } \\
\text { compete. }\end{array}$ \\
\hline \multirow[t]{3}{*}{2} & \multirow[t]{3}{*}{ Access to Permits } & Service for Licensing & $\begin{array}{l}\text { Services through OSS (online submission } \\
\text { system) } \\
\text { Government Regulations number } 6 \text { of } 2021 \\
\text { concerning the ease of doing business in the } \\
\text { regions. . }\end{array}$ \\
\hline & & 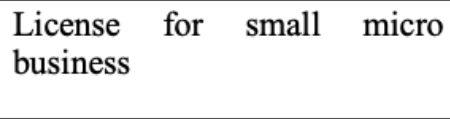 & $\begin{array}{l}\text { Provide assistance at the village and sub- } \\
\text { district levels, the Regional government office } \\
\text { for Cooperatives and SMEs Service. }\end{array}$ \\
\hline & & $\begin{array}{l}\text { Registered MSME product } \\
\text { brands }\end{array}$ & Mostly are still not officially registered \\
\hline \multirow[t]{3}{*}{3} & \multirow[t]{3}{*}{ Access to Finance } & Program for business credit & Sosialization \\
\hline & & $\begin{array}{l}\text { Grants from the government } \\
\text { office in charge of MSMEs }\end{array}$ & quota and limited \\
\hline & & $\begin{array}{l}\text { Grants from other Institutions } \\
\text { (Bank of Indonesia, Banking, } \\
\text { University Service) }\end{array}$ & Limited \\
\hline \multirow[t]{3}{*}{4} & \multirow[t]{3}{*}{$\begin{array}{l}\text { Access } \\
\text { Marketing }\end{array}$} & Exhibition & $\begin{array}{l}\text { Facilitating MSMEs to participate in } \\
\text { exhibitions }\end{array}$ \\
\hline & & GIWANG Application & $\begin{array}{l}\text { Digital platform for MSMEs, destinations and } \\
\text { tourism marketing }\end{array}$ \\
\hline & & $\begin{array}{l}\text { Provision of } \\
\text { cases/displays }\end{array}$ & $\begin{array}{l}\text { Airports, Terminals, but limited stations and } \\
\text { rentals. }\end{array}$ \\
\hline
\end{tabular}

Source: Processed data, 2021 
observations made to MSMEs, local governments related to MSMEs, and large businesses.

The results of data processing related to the research focus are presented in the following table, namely the perspective table of MSMEs, local governments and large businesses. The table is the result of data processing by researchers based on the results of focus group discussions, interviews and observations in the field.

\section{DISCUSSIONS}

\subsection{Quality of HR and MSME Production}

Based on the data shown above, the human resources of MSME actors in the city of Palembang need assistance from the local government based on training. The training in question is more specific to the business being worked on. So far, local government programs through related offices have not been specifically carried out on certain MSME products. The human resources of MSME actors not only affect the aspect of business management, but also on the quality of products that can compete. This is in line with [22] and [14] that the quality of human resources affects product quality and innovation. From the perception of large businesses, namely hotels, restaurants and tourist areas, they always prioritize product quality standards to be able to partner, so that improving the quality of MSME human resources is very necessary.

The local government of Palembang City through the department in charge of MSMEs continues to strive to improve the quality of human resources through optimizing training and budget allocation in providing production facilities for MSMEs. Likewise, big businesses through CSR programs provide training to MSME actors such as how to make Pempek, serving healthy culinary products. However, to stay competitive requires innovation.

\subsection{Access to Permit}

MSME actors in the city of Palembang still do not understand the importance of business legality and including licensing when expanding overseas markets. Some Songket SMEs have indeed done it, but only based on individual initiatives. Licensing socialization is important not only on market needs but also on the fulfillment of financing requirements by financing institutions. As stated the stipulation of regulations is a form of the government's full support in developing MSMEs [1]. The central government through Government Regulation No. 7 of 2021 concerning Ease and Protection for MSMEs is very appropriate to place MSMEs as a sector that must be prioritized by the Government and large businesses.

The ease of licensing at the Palembang City level has been implemented in accordance with the mandate of PP No. 6 of 2021 concerning the ease of doing business in the regions, namely licensing services through OSS. In general, this regulation is very helpful and accelerates the process of obtaining permits, but for MSME actors, it is constrained by the use of technology and limited access to technical information for its implementation. Meanwhile, large businesses in partnership with MSMEs prioritize MSMEs that already have valid permits and legalities

Table 3. Perspective of Large Business

\begin{tabular}{|l|l|l|l|}
\hline No & Focus of Study & Indicators & Description \\
\hline 1 & $\begin{array}{l}\text { Human Resources } \\
\text { and } \\
\text { Production Capacity }\end{array}$ & Training & CSR programs for MSME actors \\
\hline & & Product Innovation & MSME products are still not diverse \\
\hline 2 & Access to Permits & License for small micro business & $\begin{array}{l}\text { Need to set product standards in order to } \\
\text { compete }\end{array}$ \\
\hline & & Registered MSME product brands & $\begin{array}{l}\text { Prioritize MSME products that have been } \\
\text { registred }\end{array}$ \\
\hline 3 & Access to Finance & Bank Loans & Fulfillment of a number of requirements \\
\hline & & CSR Program & \begin{tabular}{l} 
very limited \\
\hline
\end{tabular} \\
\hline 4 & $\begin{array}{l}\text { Access Indonesia, Banking, University } \\
\text { Service) }\end{array}$ & $\begin{array}{l}\text { Limited } \\
\text { Marketing }\end{array}$ & $\begin{array}{l}\text { Exhibition } \\
\text { the government office in charge of MSMEs }\end{array}$ \\
\hline & & Provision of show cases/displays & Rental or collaboration systems \\
\hline
\end{tabular}

Source: Processed data, 2021 
in running their business. The purpose of licensing ownership does not mean to make it difficult but instead opens up opportunities for MSMEs to partner and access a wider market.

\subsection{Access to Finance}

MSME actors in Palembang City, based on the data shown above, are still having problems with capital and access to information about financing institutions. Whereas the KUR program (people's business credit) has long been implemented throughout Indonesia. The city of Palembang specifically has stipulated Mayor Regulation No. 49 of 2017 concerning the provision of loans to strengthen working capital for SMEs through recommendations from the Lurah and Camat. Then the grants provided by other institutions that are selective and limited, actually become a stimulus for MSMEs. The ease of trying to help MSMEs comes from various financing schemes, but the fact is that many MSME actors still do not feel this convenience. As [9] said that one of the obstacles to the development of MSMEs is limited access to financing for business operations.

One of the obstacles to MSMEs related to access to financing found in Palembang City is that there is no evaluation of the KUR program and business capital loans from the Palembang City government through the relevant agencies. The evaluation in question is the condition of MSMEs after obtaining capital, experiencing growth or not. Likewise, the identification of other MSMEs that have the potential to be developed and require sufficient capital.

\subsection{Marketing Access}

In terms of access to Marketing, MSMEs in Palembang City have carried out marketing activities digitally, but digital marketing is only at the stage of using social media. Social media is used to market the products being sold, by posting sales materials and using media to reach consumers. Some MSMEs have also used social media by using the role of endorsers to advertise products which in turn increase their product sales. This is in line with research [13] by that social media serves to introduce various products to consumers widely with various platforms available. The use of endorsers is felt directly in the increasing number of product sales, but unfortunately this increase in sales is not permanent and the upward trend occurs only for some time after the use of endorsers.

Furthermore, the use of digital media for marketing by MSMEs in Palembang City has also entered the stage of opening an online store on a digital sales platform. However, only a small number of MSMEs have done this, most of them are still limited to using digital media for product promotion. This happens because of the limited resources owned by MSMEs to manage digital stores, both in terms of management because it requires additional labor, as well as technological skills. Whereas readiness in marketing products is an important thing in product development [11]. In terms of using digital sales platforms, MSMEs still need assistance from the central or regional government. Furthermore, regarding access to marketing for MSMEs in Palembang City, the thing to note is the need for showcases both offline / physically or online / digitally to display MSME products that are managed well by the local government, in this case the relevant agencies. Although the digital platform has been used independently by some MSME actors, a showcase managed by the government will help MSMEs to be able to highlight the advantages of each product they produce.

\subsection{MSME Partnership Opportunities with Big Business in Palembang City}

Most MSMEs in Palembang City are still running alone and many have not yet established partnerships with big businesses. The role of local governments through the department in charge of MSMEs needs to be synchronized in implementing Government Regulation no. 7 of 2021 concerning the convenience and protection of MSMEs. Likewise, the Palembang City government through the Lurah and Camat regarding the mandate of implementing Mayor Regulation No. 49 of 2017 concerning Procedures for Providing Working Capital Strengthening Loans for SMEs.

A number of existing regulations will certainly strengthen MSMEs and support partnerships. The partnership between MSMEs and large businesses is aimed at cooperation related to product distribution, in this case MSMEs as product providers and large businesses as reservoirs. The principle of partnership that is built must be mutually beneficial to both parties with agreed terms. Opportunities for MSME partnerships with big businesses in the city of Palembang based on guided discussions conducted online, interviews, and observations are very wide open. However, concrete steps are needed to create a partnership, and the role of the Palembang City government in bringing together MSMEs with big businesses is very much needed. 


\section{CONCLUSION}

The quality of MSME human resources in the city of Palembang still requires various training and knowledge regarding business management and product innovation. The quality of MSME products is a requirement for large businesses because it is a guarantee of consumer satisfaction. In addition to product quality, business legality is also a requirement for large businesses to partner. MSMEs in fulfilling a number of these requirements require government assistance in this case the agency in charge of MSMEs and CSR programs carried out by hotels, restaurants, and tourism area managers (large businesses).

The benefits of access to financing through the KUR program and the Palembang City program have been felt by MSMEs. However, access to this financing is still not evenly distributed due to limited information and fulfillment of requirements. As a result, MSMEs with limited capital are hampered in accessing a wider market. In addition to limited capital, marketing is also a factor in the development of MSMEs. Sales of MSME products have been found in many digital markets, thus demanding the use of technology and participation in digital platforms. The quality of human resources, ownership of permits, ownership of business capital, and marketing are important aspects in developing MSMEs in the tourism sector and at the same time specifically that aspects of human resource quality and production capacity, ownership of permits are the main requirements in partnering with large businesses.

\section{AUTHORS' CONTRIBUTIONS}

Meitolo Hulu prepare background, theory, and data analysis.

Reagan Brian helped for complete the theory and data analysis.

Dilla Pratiyudha helped for concept, preparation of methods and data collection

Daniel Sihombing helps for concept and data collection.

Elang Kusumo helps in data collection.

\section{ACKNOWLEDGMENTS}

The authors would like to thank the Palembang Tourism Polytechnic for providing research funds and the Faculty of Tourism, Pelita Harapan University for collaboration in conducting research.

\section{REFERENCES}

[1] Andriati, S. L., \& Kamello, T. (2018). Empowerment of small and medium (SMEs) enterprises through the provision of credit with the guarantee of movable objects. E3S Web of Conferences, 52. https://doi.org/10.1051/e3sconf/20185200047.

[2] APEC (2012a). Business Growth Opportunities in the New APEC Economy. APEC SOM Steering Committee on Economic and Technical Cooperation(SCE), Tourism Working Group(TWG), November 2012. https://www.apec.org/Publications/2012/11/Bus iness-Growth-Opportunities-in-the-New-APECEconomy

[3] APEC 2014. Integrating SMEs into Global Value Chains: Policy Principles and Best Practices. $\quad$ APEC, May 2014. https://www.apec.org/Publications/2014/05/Inte grating-SMEs-into-Global-Value-Chains-

Policy-Principles-and-Best-Practices (http://publications.apec.org/Publications/2014/ 05/Integrating-SMEs-into-Global-ValueChains-Policy-Principles-and-Best-Practices)

[4] APEC 2016. Tourist Arrivals and Inclusive Growth. APEC Secretariat, August 2016. https://www.apec.org/Publications/2016/08/Tou rist-Arrivals-and-Inclusive-Growth

[5] APEC 2017. "2017 APEC High Level Statement Promoting Sustainable Tourism for an Inclusive and Interconnected Asia-Pacific." Apec.org, 2017. https://www.apec.org/MeetingPapers/Sectoral-MinisterialMeetings/Tourism/2017_tourism

[6] APEC 2017a. "Upgrading MSME's Access to Finance in a Digital Age." APEC Project Database, 2017. https://aimp2.apec.org/sites/PDB/Lists/Proposal s/DispForm.aspx?ID=2056

[7] APEC 2017b. "Developing the Tourism Workforce of the future in the APEC Region." APEC SOM Steering Committee on Economic and Technical Cooperation(SCE), Tourism Working Group(TWG), April 2017. APEC 2017b,

[8] Bougie, U. S. \& R. (2016). Research Methods for Business: A Skill-Building Approach. In John Wiley \& Sons (Seven Edit). WILEY. www.wileypluslearningspace.com.

[9] Camilleri, M. A. (2018). Nurturing travel and tourism enterprises for economic growth and competitiveness. Tourism and Hospitality Research, 18(1), 123-127. 
https://doi.org/10.1177/1467358415621947.

[10]Chris, Cooper, Fletcher, John, Fyall, A., Gilbert, D., Wanhill, S. (2008). Tourism: Principles and Practice $4^{\text {th }}$ ed. Financial Times Management.

[11] Chatterjee, S., \& Kumar Kar, A. (2020). Why do small and medium enterprises use social media marketing and what is the impact: Empirical insights from India. International Journal of Information Management, 53(February), 102103. https://doi.org/10.1016/j.ijinfomgt.2020.102103

[12] Hausemer, P. et. al. "Mapping skills and training needs to improve accessibility in tourism services." European Commission, DG Enterprise and Industry (DG ENTR), 2014. https://www.t-guide.eu/resources/study-c-finalreport_skills_ec_mastercopy_forprinting_final.pdf?i=t-guide

[13] Hulu, M., Putri, F., Nathasya, S., \& Harapan, U. P. (2021). DAMPAK MEDIA SOSIAL DAN WORD OF MOUTH TERHADAP OVERTOURISM. 8(2), 106-115.

[14] Knezović, E., Bušatlić, S., \& Riđić, O. (2020). Strategic human resource management in small and medium enterprises. International Journal of Human Resources Development and Management, 20(2), 114-139. https://doi.org/10.1504/IJHRDM.2020.106255

[15] OECD (2017). "Financing approaches for tourism SMEs and entrepreneurs." OECD Tourism Papers, March 2017. https://www.sgh.ch/fileadmin/documents/Down loads/Publikationen_Allgemein/2017/OECD_T ourism_Paper_2017 3 Financing_Approache s_for_Tourism_SMEs_and E....pdf

[16]Pierce, A. "Small and Medium-Sized Enterprises in Tourism Industries." Government of Canada, Small Business Branch, Industry Canada, Small Business Financing ProfilesSME Financing Data Initiative, December 2011.

https://www.ic.gc.ca/eic/site/061.nsf/vwapj/SBF Profile-

ProfilFPE_Dec2011_eng.pdf/\$file/SBFProfileProfilFPE_Dec2011_eng.pdf

[17] Purnawan, A., \& Adillah, S. U. (2020). Regulation of the Legality of Micro, Small and Medium Enterprises Through the Online Single Submission System To Increase Competitiveness. Jurnal Pembaharuan Hukum, $7(2)$, 159.
[18] Stacey, J. "Supporting Quality Jobs in Tourism." Organization for Economic Cooperation and Development (OECD), OECD Tourism Papers, 12 March 2015. https://www.oecd-ilibrary.org/industry-andservices/supporting-quality-jobs-intourism_5js4rv0g7szr-en (https://www.oecdilibrary.org/docserver/5js4rv0g7szren.pdf?expires $=1522349143 \& i d=i d \& a c c n a m e=$ guest $\&$ checksum $=4 \mathrm{EC} 77 \mathrm{~B} 259 \mathrm{CBA} 7 \mathrm{CB} 05 \mathrm{FDE}$ 523EB40864F6)

[19] Stein, P. et. al. Closing the Credit Gap for Formal and Informal Micro, Small, and Medium Enterprises. International Finance Corporation, IFC Advisory Services: Access to Finance, 2013.

http://documents.worldbank.org/curated/en/804 871468140039172/pdf/949110WP0Box380p0R eport0FinalLatest.pdf

[20] Stenning \& Associates Pty Ltd. Tasmanian Tourism and Hospitality Industry Workforce Development Plan. The Work Lab for the Tasmanian tourism and hospitality industry through the Tasmanian Department of State Growth, November 2016. https://www.stategrowth.tas.gov.au/_data/asset s/pdf_file/0018/142605/Tasmanian_Tourism_an d_Hospitality_workforce_development_plan_fi nal.pdf

[21]Thais Gonzales-Torres, Jose-Luis RodriguezSanchez, E. P.-B. (2021). Since January 2020 Elsevier has created a COVID-19 resource centre with free information in English and Mandarin on the novel corona virus. The COVID-19 resource centre is hosted on Elsevier onnect, the company's public news and information website . International Journal of Hospitality Management, 92, 1-11.

[22] Verreynne, M. L., Williams, A. M., Ritchie, B. W., Gronum, S., \& Betts, K. S. (2019). Innovation diversity and uncertainty in small and medium sized tourism firms. Tourism Management, 72(April 2018), 257-269. ttps://doi.org/10.1016/j.tourman.2018.11.019

[23] Wiesner, R., Chadee, D., \& Best, P. (2018). Managing Change Toward Environmental Sustainability: A Conceptual Model in Small and Medium Enterprises. Organization and Environment, 31(2), 152-177. https://doi.org/10.1177/1086026616689292

https://doi.org/10.26532/jph.v7i2.10990 